\title{
URGENSI CIVIC EDUCATION DALAM MEMBANGUN BUDAYA DEMOKRASI MENUJU MASYARAKAT MADANI INDONESIA: SEBUAH PENDEKATAN FIQH SIYASAH
}

\author{
Oleh: Muhammad Iqbal* \\ Fakultas Syariah UIN Sumatera Utara \\ J1. Willem Iskandar Pasar V Medan Estate \\ e-mail: dr.muhammadiqbali@yahoo.com
}

\begin{abstract}
In the current history of Indonesia, discussions concerning the implementation of democracy seem to be ups and downs. In general, it can be said that the implementation of democracy has not met the noble ideas of the 1945 Proclamation. Consequently, civilized society development as promoted by the second principle of Pancasila has not been completely realized. This article therefore aims at presenting a description of political journeys of Indonesian and a model of civic education in developing democracy in order to achieve the ideal civil society. This can realized prioritizing understanding towards people's rights, educating people to be more critical toward current issues, and promoting open mindedness and accepting all the existing differences.
\end{abstract}

Kata kunci: civic education, demokrasi, masyarakat madani, politik

\section{PENDAHULUAN}

D emokrasi adalah budaya politik modern yang dianut oleh hampir seluruh belahan dunia. Meskipun di sana-sini banyak juga kritikan terhadap demokrasi, sistem ini diyakini sebagai yang terbaik dari berbagai sistem politik yang ada, karena demokrasi merupakan kekuasaan yang melibatkan rakyat secara aktif dalam berbagai proses politik. Dalam demokrasi ada kontrol dan pertanggungjawaban terhadap kekuasaan, sehingga penyimpangan atas kekuasaan tersebut bisa dicegah sedini mungkin. Karena itu, wajar sekali kalau sistem demokrasi dijadikan alternatif sistem politik di negara-negara di dunia.
Indonesia juga tidak ketinggalan menganut sistem ini. Meskipun dalam perjalanannya demokrasi Indonesia mengalami pasang-surut dan penyimpangan, pasca tumbangnya rezim Orde Baru, kehidupan demokrasi mulai ditata kembali. Tujuannya tidak lain adalah menciptakan bangsa Indonesia yang berkeadilan dan masyarakat yang kuat berhadapan dengan kekuasaan. Dalam istilah sekarang, masyarakat tersebut sering disebut dengan masyarakat madani, civil society, masyarakat berkeadaban dan lainlain.

Pengembangan budaya demokrasi dalam mencapai masyarakat madani ini memerlukan sinergi antara semua pihak. Karena itu, pendidikan adalah faktor terpenting

* Penulis adalah Dosen pada Fakultas Syariah UIN Sumatera Utara. 
dalam pembelajaran dan pembudayaan demokrasi ini. Oleh karena itu, pendidikan kewargaan atau civic education adalah hal yang mutlak. Dari sinilah mulai dikembangkan nilai-nilai demokrasi pada segenap komponen masyarakat Indonesia, sehingga cita-cita pembentukan masyarakat madani dapat terwujud.

Tulisan ini hendak menyoroti aspek-aspek demikian. Secara sistematis, tulisan ini akan membicarakan tentang civic education, pengembangan budaya demokrasi masyarakat, pasang surut demokrasi di Indonesia dan pembelajaran demokrasi dalam rangka menciptakan masyarakat berkeadaban.

\section{CIVIC EDUCATION DAN MASYA- RAKAT MADANI}

Secara harfiah "civic" berarti kewargaan dan "education" berarti pendidikan. Kalau kedua kata ini digabungkan, maka civic education berarti pendidikan kewargaan. Ada beberapa batasan yang dibuat oleh berbagai ahli tentang masalah civic education ini. Henry Randall Waite menyatakannya sebagai ilmu tentang kewarganegaraan, hubungan seseorang dengan orang lain dalam perkumpulan-perkumpulan yang terorganisir, hubungan seorang individu dengan negara. Sumantri mendefinisikannya sebagai ilmu kewarganegaraan yang membicarakan hubungan manusia dengan manusia dalam perkumpulan yang terorganisasi (sosial, ekonomi, dan politik) dan individu dengan negara. Sementara Edmonson menyatakannya sebagai ilmu tentang pemerintahan dan kewarganegaraan (Ubaidillah dan Razak, 2006: 5).
Dari beberapa pengertian di atas bisa diambil satu benang merah bahwa civic education adalah ilmu yang mengkaji tentang kewargaan dalam hubungannya antara satu warga negara dengan warga negara lain dan warga negara dengan pemerintah (kekuasaan). Pendidikan kewargaan akan menempatkan warga negara sebagai subjek, bukan objek, berhadapan dengan negara. Karena itu, pendidikan kewargaan akan menyadarkan warga terhadap hak-hak mereka. Setidaknya ada tiga tema besar ketika kita bicara tentang civic education, yaitu demokrasi, hak asasi manusia (HAM) dan masyarakat madani (Ubaidillah dan Razak, 2006: 12). Ketiga hal ini saling terkait satu sama lainnya. Pendidikan demokrasi meniscayakan penghargaan dan penghormatan terhadap hak asasi manusia. Kalau kedua hal ini dapat berjalan dengan baik, maka pembentukan masyarakat madani.

Masyarakat madani adalah istilah yang dipinjam dari bahasa Arab. Istilah ini untuk pertama kali digagas oleh Anwar Ibrahim, mantan Wakil Perdana Menteri Malaysia ( Ubaidillah dan Razak, 2006: 302). Secara etimologis, madani seakar dengan tamaddun, yang berarti kota atau peradaban. Ini menunjukkan bahwa hanya masyarakat kota yang menetap yang dapat membangun sebuah peradaban. Kota Yasrib dikatakan dengan "Madinah" karena ketika Nabi Saw. hijrah sudah tertanam sebuah cita-cita beliau untuk membentuk masyarakat Madinah sebagai masyarakat yang berperadaban menjunjung tinggi nilai-nilai kemanusiaan dan etika. Dari pengertian ini maka dapat dikatakan bahwa masyarakat madani adalah sebuah 
sistem sosial masyarakat yang dibangun atas prinsip-prinsip moral yang menjamin keseimbangan antara kebebasan individu dan kestabilan masyarakat. (Muhammad Iqbal, 2014: 36-37)

Dalam istilah masyarakat madani ini yang ditonjolkan adalah penguatan peran masyarakat. Anggota masyarakat madani yang lebih berperan aktif dalam penciptaan masyarakat berkeadaban tersebut. Dalam hal ini posisi negara adalah sebagai wadah yang mengakomodasi berbagai kepentingan di dalam masyarakat, bukan sebagai pemegang komando tunggal yang tidak boleh dibantah. Negara harus mengapresiasi aspirasi kelompok-kelompok masyarakat dan merajut perbedaanpebedaan yang ada ke dalam mosaik yang indah. Ibarat sebuah konser, perbedaan-perbedaan yang ada di dalam masyarakat, kalau ditangani dengan baik dan benar, akan menghasilkan alunan nada-nada musik yang indah. Karena itu, ada beberapa unsur yang harus diwujudkan dalam pengembangan masyarakat madani, yaitu:

1. Adanya ruang publik yang bebas Warga masyarakat harus diberikan kebebasan untuk mengemukakan pendapat dan mengekspresikan kreasinya. Semua warga masyarakat memiliki hak yang sama untuk melakukan peran sosial dan politik serta memperoleh akses terhadap kegiatankegiatan yang bersifat publik tanpa rasa takut. Pembatasan ruang publik dan ancaman-ancaman fisik maupun mental merupakan pelanggaran terhadap hak masyarakat yang paling asasi, yaitu terbebas dari rasa takut. Ini tentu bertentangan dengan cita masyarakat madani.

\section{Demokrasi}

Tanpa demokrasi mustahil akan terwujud masyarakat madani. Dalam demokrasi semua warga masyarakat memiliki hak untuk menentukan sikap politik dan mengontrol kekuasaan. Tentu saja dengan cara-cara yang konstitusional.

3. Toleransi

Masyarakat madani mengutamakan pengembangan toleransi terhadap seluruh warganya. Dalam masyarakat madani setiap indivi$\mathrm{du}$ harus dapat menghargai perbedaan yang ada. Bagaimanapun, tidak mungkin orang memiliki pandangan, sikap hidup dan cara berpikir yang sama. Karena itu, masing-masing anggota masyarakat harus menghormati pandangan orang lain, sejauh tidak mengganggu kepentingannya.

4. Pluraritas

Kemajemukan atau pluraritas merupakan prasyarat bagi terwujudnya masyarakat madani. Kemajemukan merupakan sikap penuh pengertian terhadap orang lain dan kesediaan untuk bekerja sama dengan orang lain. Dengan semangat pluraritas, orang terbiasa untuk berpikir positif terhadap orang lain. Dalam pandangan agama Islam, pluralitas adalah suatu keniscayaan dan merupakan hukum Allah yang tidak bisa terelakkan. 


\section{Keadilan sosial}

Keadilan sosial adalah adanya keseimbangan antara hak dan kewajiban setiap warga masyarakat, yang mencakup seluruh aspek kehidupan: ekonomi, politik, sosial, budaya, dan pengetahuan. Keadilan ini bukan berarti memberikan sesuatu secara sama rata kepada semua orang, melainkan memberikan sesuatu yang memang layak dan tepat pada proporsinya. (Ubaidillah dan Razak, 2006: 315-316).

Kalau berkaca pada sistem masyarakat madani yang dibangun Nabi Muhammad SAW di Madinah 15 abad yang lalu, kita akan melihat dasar-dasar hubungan masyarakat yang beliau bangun yang sekarang menjadi pandangan hidup modern di dunia. Dasar-dasar itu, menurut Nurcholish Madjid dalam Bosco Carvallo dan Dasrizal (1983:11) adalah hubungan bertetangga baik antara seluruh warga negara, tanpa memandang asal-usul suku dan agama, saling membantu menghadapi musuh bersama dan kewajiban bela negara, membela orang yang teraniaya, saling menasihati dan menghormati kebebasan beragama serta kemerdekaan hubungan ekonomi antar golongan. Menurut Munawir Sjadzali (1991: 15-16), Piagam Madinah sebagai konstitusi Negara Madinah memberi landasan bagi kehidupan bernegara dalam masyarakat yang majemuk di Madinah. Landasan tersebut ialah, pertama, semua umat Islam adalah satu kesatuan walaupun berasal dari berbagai suku dan golongan; kedua, hubungan internal komunitas Muslim dan hubungan eksternal antara komunitas Muslim dengan nonMuslim, didasarkan pada prinsip bertetangga baik, saling menolong dalam menghadapi musuh bersama, membela orang yang teraniaya, saling menasihati dan menghormati kebebasan beragama. Nurcholish Madjid menegaskan bahwa Piagam Madinah memuat pokok-pokok pikiran yang mengagumkan. Dalam Piagam Madinah ini untuk pertama kali dirumuskan ide-ide yang sekarang menjadi pandangan hidup modern di dunia, seperti kebebasan beragama, hak setiap kelompok untuk mengatur hidup sesuai dengan keyakinannya, kemerdekaan hubungan ekonomi antargolongan serta kewajiban bela negara.

\section{PASANG SURUT DEMOKRASI PANCASILA DI INDONESIA}

Demokrasi adalah alat penting dalam pencapaian cita-cita masyarakat madani di Indonesia. Demokrasi Pancasila merupakan tradisi bangsa Indonesia yang sudah tertanam lama dalam masyarakat. Dalam kelompok-kelompok masyarakat, tradisi ini terlembaga dalam bentuk rapat dan musyawarah dalam menentukan sesuatu bagi kepentingan masyarakat tersebut.

Dalam praktiknya, demokrasi di Indonesia pada masa pascakemerdekaan mengalami dinamika dan pasang surut. Pada periode perjuangan kemerdekaan, para pejuang bangsa terlibat pembicaraan alot dalam menentukan arah ke mana bangsa Indonesia yang akan diproklamasikan ini akan dibawa. Pada awal abad ke-20, ada dua arus utama yang berkembang, yaitu kelompok Islam dan kelompok 
nasionalisme yang netral agama. Polarisasi ini terlihat umpamanya dengan adanya Sarekat Islam, Jong Islamieten Bond, Muhammadiyah dan NU serta Majelis Islam A'la Indonesia (MIAI) di satu pihak dan Budi Oetomo, Jong Java dan Taman Siswa di pihak lain. (Muhammad Iqbal dan Amin Husein Nst., 2013: 272)

Perdebatan muncul ketika bangsa Indonesia menyusun format ideal negara dalam Badan Penyelidik Usaha-usaha Persiapan Kemerdekaan Indonesia (BPUPKI). Perdebatan tersebut akhirnya melahirkan kesepakatan lahirnya Pancasila yang mengakomodasi kepentingan semua anak bangsa Indonesia. Pascakemerdekaan, Pemerintah mengeluarkan Maklumat Pemerintah No. X pada 16 Oktober 1945 dan Maklumat 3 Nopember 1945. Maklumat ini berisi tentang perubahan sistem pemerintahan Indonesia dari presidensial ke bentuk parlementer dan diberinya kesempatan bagi masyarakat Indonesia untuk mendirikan partai-partai guna menyalurkan aspirasi politiknya. Dalam sistem ini Indonesia menampung banyak partai yang akan ikut serta dalam pemilu 1955.

Pada 29 September 1955 pemilu pertama di Indonesia dapat dilaksanakan. Pemilu ini diikuti 39 parpol, 46 organisasi, 59 orang mewakili perorangan dan 34 kelompok kumpulan. Semuanya memperebutkan 257 kursi. Dari pemilu ini, ada tiga ideologi yang meraih suara terbesar dan akan bersaing di Konstituante, yaitu Islam, nasionalis dan komunis. Empat besar pemenang pemilu adalah PNI memperoleh PNI memperoleh 57 kursi (22,3\%), Masyumi 57 kursi $(20,9 \%)$, NU 45 kursi $(18,4 \%)$, dan PKI 39 kursi (16,4\%). (Herbert Feith, 1957: 58).

Pertarungan ideologi terjadi di Konstituante. Partai-partai yang membela Islam sebagai dasar negara seperti Masyumi, NU, PSII dan Perti satu suara menghadapi PNI dan kawan-kawan yang mengusung Pancasila. Dalam perdebatan tersebut, tidak tercapai kata sepakat. Masing-masing mempertahankan pendiriannya, namun tidak mampu meyakinkan pihak lain. Soekarno yang tidak sabar akhirnya mengeluarkan Dekrit Presiden pada 5 Juli 1959. Soekarno membubarkan Konstituante dan menyatakan Indonesia kembali ke UUD 1945. Dengan dekrit ini Soekarno juga telah mengintervensi Konstituante dan berusaha memusatkan kekuasaan di tangannya saja. (Iqbal dan Nasution, 2013: 282)

Pascadekrit, Soekarno memaksa pembubaran Masyumi pada 17 Agustus 1960, karena menolak Demokrasi Terpimpin. Partai-partai Islam seperti NU, PSII dan Partai Tarbiyah Islamiyah ikut bersama Demokrasi Terpimpin. Dalam Demokrasi Terpimpin ini PKI benarbenar leluasa menguasai perpolitikan Indonesia. Akhirnya Demokrasi Terpimpin bubar bersama kegagalan pemberontakan PKI, 1965. (Maarif, 1988: 64).

Gagalnya pemberontakan PKI dan jatuhnya Soekarno menandai bangkitnya era baru yang oleh pendukungnya disebut Orde Baru. 
Kelahirannya ditandai oleh pemberian mandat Surat Perintah Sebelas Maret 1966 atau Supersemar dari Soekarno kepada Soeharto untuk mengatasi situasi setelah pemberontakan PKI. Soeharto, dengan ABRI (sekarang TNI) dan bantuan umat Islam akhirnya dapat menguasai keadaan. Soeharto ingin melaksanakan demokrasi Pancasila secara murni dan konsekuen.

Pada awal pemerintahannya, banyak partai yang muncul. Akan tetapi, pada 1973, Soeharto mengambil kebijakan penyederhanaan partai dan konsep floating mass (massa mengambang). Ini dianggap efektif untuk mengontrol partai dan memusatkan kekuasaan di tangan penguasa. Partai politik tidak boleh mengembangkan aktivitasnya di tingkat kecamatan dan desa. Dengan demikian, partai terlepas dari konstituennya, sehingga tidak ada hubungan emosional antara keduanya. (Iqbal dan Nasution, 2013: 296)

Partai-partai yang berbasis Islam berfusi ke dalam Partai Persatuan Pembangunan (PPP), sedangkan partai yang berbasis nasionalis dan Kristen bergabung ke dalam Partai Demokrasi Indonesia (PDI). Dengan fusi ini, rezim Orba semakin mudah mengkooptasi partai. Selama kepemimpinannya, Soeharto menjalankan kekuasaan yang jauh dari watak demokratis. Banyak kebijakan Soeharto yang bertentangan dengan demokrasi Pancasila. Akhirnya, setelah 32 tahun berkuasa, pada Maret 1998 Soeharto yang didukung sepenuhnya oleh ABRI jatuh dan ia digantikan oleh Wakilnya BJ. Habibie.

Dalam kepemimpinannya, Habibie berusaha memperbaiki situasi sosial politik yang sudah kacau. Beberapa kebijakan yang memihak kepada demokrasi digulirkan Habibie. Habibie membebaskan tahanan politik yang dipenjarakan Soeharto, mempercepat pemilu, menggenjot nilai tukar rupiah hingga Rp7.000/US Dolar. (Pratiknya, 1999: 207). Sayangnya kebijakannya tidak didukung sepenuhnya oleh rakyat. Pertanggungjawabannya ditolak MPR sehingga ia gagal untuk maju mencalonkan diri sebagai Presiden masa berikutnya.

Ketika proses pemilihan Presiden RI di MPR, partai-partai Islam memiliki satu suara dalam Poros Tengah yang digalang oleh $\mathrm{M}$. Amien Rais untuk menggolkan Abdurrahman Wahid sebagai Presiden. Kerja sama ini berhasil ketika terjadi perseteruan yang semakin memanas antara calon Presiden Habibie dari Partai Golkar dan Megawati dari PDI-P. Amien Rais bersama partai-partai Islam lainnya, dalam Sidang umum MPR 20 Oktober 1999, berhasil mendudukkan Wahid sebagai Presiden RI mengalahkan Megawati. Untuk "membujuk" Megawati dan pendukungnya yang marah, akhirnya ia diproyeksikan sebagai Wakil Presiden bertarung dengan Hamzah Haz. Mega berhasil menjadi wakil Wahid mengalahkan Hamzah.

Kepemimpinan Wahid ternyata membawa masalah. Banyak kebijakannya yang tidak demokratis. Bahkan Wahid akan membubarkan MPR melalui Dekrit Presiden. Tanggal 23 Juli 2001 Wahid benar-benar mengeluarkan dekrit yang isinya membubarkan DPR dan MPR, mengembalikan kedaulatan kepada rakyat dan membentuk Komisi Pemilihan 
Umum untuk mempersiapkan pemilu dalam waktu satu tahun dan membubarkan Golkar. Saat itu juga, pukul 08.00, Amien Rais membuka Sidang Istimewa MPR dengan agenda pemungutan suara; apakah menerima atau menolak dekrit. Dari 601 orang anggota yang hadir, 599 orang menolak dekrit. Hari itu juga berakhirlah jabatan Wahid sebagai Presiden dan naiklah Megawati menggantikannya. (Denny Indrayana, 2007: 250-251).

Salah satu peran yang dimainkan Megawati adalah mempersiapkan dan melaksanakan pemilu kedua pada masa reformasi. Ada 24 partai politik peserta pemilu 2004. Dari pemilihan presiden terdapat perkembangan baru yang menarik. Pemilihan Presiden tahun 2004, sesuai dengan amanat UUD 1945 yang telah diamandemen, dilakukan oleh seluruh rakyat yang berhak, bukan lagi oleh MPR. Dalam pemilu langsung yang pertama ini muncul lima pasangan calon presiden-wakil presiden, yaitu Susilo Bambang Yudhoyono-M. Jusuf Kalla, M. Amien Rais-Siswono Yudhohusodo, Megawati-Hasjim Muzadi, WirantoSolahuddin Wahid dan Hamzah HazAgum Gumelar.

Dalam pemilu yang berlangsung dua putaran ini pasangan SBYKalla akhirnya memenangi pertarungan menuju kursi RI-1 dan 2 mengalahkan Mega-Hasyim. Pada pemilu berikutnya, 2009, SBY berpasangan dengan Boediono. Pemilu 2009 ini berlangsung hanya satu putaran dan SBY-Boediono menang mengumpulkan lebih 60 persen sua- ra, mengalahkan Megawati-Prabowo dan Jusuf Kalla-Wiranto. Dalam periode kedua kepemimpinannya, ternyata banyak masalah yang dihadapi SBY. Penyimpangan kekuasaan dan korupsi oleh pembantu-pembantu SBY membuat pemerintahannya tidak berjalan semulus periode pertama.

Pada pemilu 2014, muncul dua pasangan capres-cawapres, yaitu Prabowo-Hatta Radjasa dan Joko Widodo-M. Jusuf Kalla. Pemilu berjalan alot dan Jokowi-JK akhirnya menang tipis atas Prabowo-Hatta. Karena tidak puas pada hasil pemilu, pasangan Prabowo-Hatta mengajukan gugatan ke Mahkamah Konstitusi. Namun gugatan tersebut ditolak dan akhirnya Jokowi dilantik sebagai Presiden RI yang ketujuh. Beberapa waktu kepemimpinannya, kebijakan Jokowi-JK ternyata jauh dari harapan rakyat.

Dari perjalanan selama 70 tahun Indonesia merdeka, ternyata pelaksanaan demokrasi mengalami pasangsurut. Ada saat Indonesia menjalankan demokrasi yang sangat liberal dengan sistem parlementer, namun ada pula masanya demokrasi hanya menjadi hiasan bibir penguasa dalam setiap pidatonya. Barulah pada 1998 Indonesia kembali menyusun format demokrasi yang ideal, meskipun dalam pelaksanaannya masih banyak hal yang perlu disempurnakan.

Secara umum, kehidupan demokrasi Indonesia masih belum sesuai dengan harapan dalam rangka mencapai masyarakat madani. Apalagi sekarang, demokrasi menjadi alat bagi petualang-petualang politik 
untuk merebut dan memperturutkan syahwat kekuasaan. Fenomena konflik antarpartai maupun internal partai, penghalalan segala cara untuk mendapatkan dan mempertahankan kekuasaan dan penyelewengan kekuasaan yang berakhir dengan dipenjarakannya orang-orang yang sedang atau pernah berkuasa memperlihatkan bahwa kita masih tertatihtatih dalam menjalankan demokrasi.

\section{PENDIDIKAN DEMOKRASI PANCASILA}

Pertanyaannya adalah, mengapa selama 70 tahun perjalanan bangsa ini demokrasi belum sepenuhnya berjalan? Mengapa kita masih terseok-seok dan cenderung jalan di tempat, kalau bukan mundur? Jawabannya agaknya karena kita gagal melakukan pendidikan demokrasi Pancasila bagi anak bangsa. Demokrasi Pancasila hanya menjadi hafalan di kepala anak didik dan tidak membumi dalam realitas kehidupan masyarakat.

Akibatnya, budaya politik di Indonesia pun cenderung homo homini lupus; sebagian kita menjadi srigala bagi yang lain, siapa yang kuat akan memangsa yang lemah. Kekuasaan yang harusnya diarahkan untuk berbuat yang terbaik bagi kesejahteraan dan kemakmuran rakyat, ternyata mengalami distorsi dan disalahgunakan untuk meraup keuntungan pribadi dan golongan. Syahwat kuasa merabunkan mata penguasa untuk menempuh jalan yang benar.

Pendidikan demokrasi sejatinya mengantarkan anak bangsa, baik pemimpin maupun rakyat, untuk mengerti dan melaksanakan hak dan kewajiban masing-masing. Pemegang kekuasaan menyadari bahwa kekuasaan di tangannya adalah sebuah kesempatan untuk berbakti kepada negara dan meningkatkan kehidupan masyarakat. Ia akan mengerti batas-batas kewenangan dan tidak akan melabraknya. Di sisi lain, pendidikan demokrasi menempatkan warga negara sebagai subjek, bukan objek, berhadapan dengan negara. Karena itu, pendidikan demokrasi akan menyadarkan warga terhadap hak-hak mereka.

Dari paparan di atas, jelas sekali bahwa penegakan masyarakat madani ditandai oleh prinsip demokrasi dan menjunjung tinggi hak (HAM). Namun demikian, penegakan ini bukanlah kerja sekali jadi. Diperlukan upaya serius dan proses pembelajaran berkesinambungan dalam penciptaan budaya demokrasi dalam kehidupan sosial dan penegakan HAM dalam masyarakat.

Ada beberapa hal yang layak dikembangkan dalam pendidikan demokrasi ini, di antaranya:

1. Perlu pendidikan bagi masyarakat tentang hak-hak mereka sebagai warga negara. Masyarakat tidak boleh buta tentang apa yang harus ia dapatkan dari negara. Warga negara berhak tahu dan mendapatkan hak-hak mereka secara proporsional dari negara (pemerintah). Hubungan antara warga negara dengan pengelola negara adalah berdasarkan kontrak sosial. Warga negara telah memberikan sebagian hak mereka untuk diatur dan diperintah oleh pengelola negara melalui pemilu. Warga negara juga wajib patuh terhadap aturan yang dibuat pengelola negara. Sebaliknya, warga negara 
berhak mendapat perlindungan dan pelayanan publik dari pengelola negara. Pengelola wajib menjalankan pemerintahan sesuai dengan prinsip-prinsip keadilan. Kita mendirikan negara adalah untuk mencapai kesejahteraan dan kemakmuran bersama. Semua kebijakan pengelola negara harus diarahkan pada tujuan demikian. Kalau kebijakan pengelola negara bertentangan dengan prinsip demikian, maka rakyat berhak menarik kembali mandat yang mereka berikan. Karenanya, rakyat harus memiliki pemahaman dan pengetahuan yang baik tentang hak-hak yang harus mereka terima dari pemerintah. Rakyat harus mendapatkan pendidikan dan pencerdasan.

2. Dalam kaitannya dengan hal di atas, perlu pembelajaran bagi warga negara agar mereka tidak kurang perhatian dan kurang tanggap terhadap permasalahanpermasalahan kenegaraan yang berkembang. Warga negara harus melek terhadap masalah yang terjadi dalam bangsa Indonesia. Dengan demikian, mereka merasa memiliki negara dan bangsa ini, karena merekalah pada hakikatnya pemilik kekuasaan.

Ketika ada hal-hal yang tidak sesuai dengan aturan-aturan kenegaraan yang baku, masyarakat dapat melakukan kristalisasi gerakan untuk menuntut perubahan agar kembali ke jalan yang benar. Ketika ada pejabat publik yang melakukan penyelewengan kekuasaan, rakyat berhak melakukan kontrol terhadap proses hukum yang sedang berjalan terhadap dirinya. Rakyat berhak juga melakukan kontrol atas kinerja lembaga kekuasaan, baik eksekutif, legislatif maupun yudikatif. Jangan biarkan berkembang sikap apatis dan tidak mau peduli masyarakat terhadap proses bernegara di Indonesia. Karena itu, harus ada pembelajaran terus menerus untuk rakyat tentang proses politik yang berkembang di negara kita.

Warga negara juga perlu kritis terhadap informasi yang berkembang. Warga negara berhak tahu atas informasi yang sebenarnya terjadi dalam masyarakat dan negara. Mereka berhak mendapat pengetahuan yang memadai tentang pemimpin mereka. Jangan mereka dicekoki hanya dengan pencitraan sosok tertentu untuk kepentingan kelompok atau golongan tertentu saja. Ini namanya pembodohan sistemik. Karenanya, peranan media massa di sini perlu dalam pendidikan politik warga negara, jangan terjebak sebagai media partisan yang memihak kepada kelompok tertentu.

3. Pembudayaan demokrasi bukan hanya sekadar wacana, melainkan harus membumi dalam realitas kehidupan. Pembelajaran berdemokrasi harus sejak dini ditanamkan dalam kehidupan. Ini bisa dilakukan umpamanya di kelas dalam setiap tingkat pendidikan. Anak-anak didik diajarkan untuk mengeluarkan pendapat dan dibiasakan berbeda pen- 
dapat dengan kawan-kawannya. Ajak mereka berargumentasi mempertahankan pendapat yang diyakininya benar, tapi harus dibarengi dengan kesediaannya untuk menghargai pendapat kawannya yang tidak sesuai dengan pendapatnya. Guru atau dosen jangan menjadi hakim yang memvonis betul-salah, tapi bertindaklah sebagai wasit yang mengarahkan, layaknya sebuah pertandingan olah raga. Dengan begitu siswa/mahasiswa dapat mengeluarkan pendapatnya dengan bebas tanpa takut salah. Sistem pembelajaran demikian akan menjadikan siswa/ mahasiswa sebagai subjek bukan objek pembelajaran. Mereka dirangsang melalui cara belajar yang demokratis untuk bersikap partisipatif, aktif, kreatif, dan menantang. Cara-cara ini akan efektif dalam pengalaman mereka ketika sekolah/kuliah sangat berharga bagi proses pembudayaan nilai-nilai demokrasi dan HAM dalam kehidupan sosial. pembudayaan demokrasi, karena

\section{PENUTUP}

Dari paparan di atas jelaslah bahwa demokrasi yang menjadi citacita politik bangsa Indonesia dalam menuju masyarakat madani masih belum sepenuhnya berjalan. Sepanjang perjalanan bangsa Indonesia, demokrasi sering dijadikan alat bagi legitimasi dan justifikasi perilaku politik sebagian pemegang kekuasaan. Ini yang membuat cita-cita masyarakat madani belum dapat terwujud ke dalam realitas. Karenanya, pendidikan demokrasi yang mengutamakan pemahaman yang benar tentang hak-hak rakyat, pencerdasan rakyat agar bersikap kritis terhadap permasalahan yang berkembang dan pengembangan sikap terbuka serta menerima perbedaan yang ada adalah hal mutlak dikembangkan bagi segenap bangsa Indonesia.

Inilah beberapa poin pemikiran yang dapat dikembangkan dalam pembelajaran politik dan pembudayaan demokrasi Pancasila. Kalau ini berhasil dilakukan, maka Indonesia akan menjadi bangsa demokratis yang besar dan disegani. Keterpurukan bangsa yang sekarang menggelayuti akan dapat teratasi.

Indrayana, Denny. 2007. Amandemen UUD 1945 Antara Mitos dan Pembongkaran, Bandung: Mizan.

Feith, Herbert, “The Indonesian Elections of 1955". 1957. New York: Modern Indonesia Project Southeast Asia Program Cornell University Itacha.

\section{DAFTAR PUSTAKA}

Carvallo, Bosco dan Dasrizal, et al. 1983. Aspirasi Umat Islam Indonesia, Jakarta: LEPPENAS. 
Indonesia Kontemporer, Jakarta: Prenada Media.

Maarif, Ahmad Syafii, Islam dan Politik di Indonesia pada Masa Demokrasi Terpimpin 1959-1965. 1988.Yogyakarta: IAIN Sunan Kalijaga Press,

Pratiknya, Ahmad Watik, et al. 1999. Pandangan dan Langkah
Reformasi B.J. Habibie, Jakarta: Rajawali Pers, 1999.

Sjadzali, Munawir, Islam dan Tata Negara. 1991. UI Press.

Ubaedillah, A. Dan Abdul Rozak, et al., 2006. Demokrasi HAM dan Masyarakat Madani, Jakarta: ICCE dan Prenada Media. 